\title{
LAKITAS DE VINILO EN ARICA ${ }^{1}$
}

Gerardo Mora Rivera ${ }^{2}$

\section{Presentación}

Actualmente, en la ciudad de Arica ${ }^{3}$, las lakitas ${ }^{4}$-instrumentos aerófonos de data prehispánicason fabricadas, de preferencia, con tubos de Policloruro de Vinilo (PVC), producto industrial cuyo fin original es la conducción de aguas y cables eléctricos por el interior de las construcciones. Existen ductos con distintas características técnicas, señaladas por su color, según sirvan para transportar agua potable (celeste), aguas servidas (gris), tendidos eléctricos (naranjo), etc. Desde su masificación, a mediados del siglo XX, están experimentando aceleradas mejoras, lo que implica que en cada década aparecen nuevos tipos de tuberías, con propiedades específicas. En las lakitas, los tubos son cerrados en su extremo distal con trozos sacados de antiguos discos de vinilo. El doble posicionamiento de dicho material en su ensamblaje, anima a llamarlas "lakitas de vinilo", aunque sus fabricantes e intérpretes acostumbran a llamarlas "de PVC" o "de plástico".

Suele suceder que describir un artefacto con conceptos ajenos a su entorno, es un pie forzado dentro de la antropología y otras disciplinas. No obstante, opera como una estrategia escritural efectiva para acercar al lector al fenómeno estudiado.

Siguiendo la clasificación de Tranchefort, los tecnólogos en sonido Godoy y Nadiar, describen a

\footnotetext{
${ }^{1}$ Este artículo presenta resultados obtenidos en los proyectos FONDART No 3336-7 "Lakitas de Arica" y FONDART N ${ }^{\circ}$ 71783 “Arica. Lakitas", ejecutados entre los años 2008 y 2010, por [AZAPA]. Grupo que reúne a Andrés Fortunato [Ingeniero en Sonido y Magíster (c) en Economía], César Borie [Arqueólogo], Gerardo Mora [Antropólogo Social] y Juan Solar [Documentalista]. Por otra parte, varias de las reflexiones teóricas expuestas en este artículo, provienen de la participación de su autor en el proyecto FONDECYT N 1090110 "Discursos andinos coloniales. Soportes, confluencia y transformaciones", dirigido por el etnohistoriador José Luis Martínez.

${ }^{2}$ Colaborador proyecto FONDECYT No 1090110, AZAPA Producciones Ltda, Chile.

${ }^{3}$ En este estudio se ha privilegiado un enfoque local, sin desconocer que se abordan fenómenos y procesos que son parte de un espacio mayor, Los Andes. Entendido éste como un "lugar antropológico", concepto tomado de Wrigth (1998) y esbozado para el caso del Norte Grande de Chile en Mora (2009:capítulo II).

${ }^{4}$ Coloquialmente, fuera del área donde se realizó el estudio aquí presentado, este instrumento es llamado "zampoña", y de manera más genérica, "flauta de Pan". Además es conocido entre músicos e investigadores como "siku", "antara", "phusa", "laka", etc. En ciertas ocasiones, cuando se realizan distinciones más finas, es puesto en relación con otros instrumentos que llevan dichas denominaciones. Por último, el origen etimológico del vocablo usado para designarlo también es objeto de discusión. En pocas palabras, no existe acuerdo sobre el nombre que ha de recibir. Para este artículo se ha optado por utilizar la expresión y grafía usadas comúnmente, aunque no de manera exclusiva ni excluyente, por sus fabricantes e intérpretes. Esto en consideración a las particularidades observadas en el caso estudiado: material de fabricación, forma de ejecución, área de distribución, etc.
} 
este instrumento musical ${ }^{5}$ como un aérofono con embocadura de flauta, donde "la columna de aire en el interior del instrumento es inducida a vibrar por la acción de un chorro continuo de aire enviado contra una arista o bisel fijo al instrumento en cuestión" (Godoy y Nadiar, 1988: 6). Se trata de "un instrumento de viento sin canal de insuflación, es decir, sin boquilla, construido a partir de tubos de diámetros similares cerrados por un extremo, ordenados por longitud la cual determina la altura o nota a la que sonará cada tubo" que, para el caso de Arica -aunque no de manera única- es afinado "en escala diatónica y la tonalidad más común es Sol mayor, sin embargo, en los últimos años muchas lakitas se afinan en La o Do mayor", de esta manera, "al ser más cortos los tubos se requiere de menos aire para tocar, así los sopladores se cansan menos, y su mayor altura aumenta la sonoridad, factor crucial en los contrapunteos ${ }^{6,}$ (Fortunato, 2010).

El presente trabajo mira, y escucha, este cambio en las comparsas de lakitas. Vale decir, agrupaciones musicales cuyo formato instrumental está compuesto por un número idealmente par de lakitas -el mínimo óptimo parece ser seis- y tres instrumentos de percusión: caja, bombo y platillo. Los sopladores su ubican enfrentados en dos hileras paralelas y tocan usando una técnica denominada como “diálogo musical”, por el musicólogo puneño Américo Valencia (1982). Esta técnica existe al menos desde el desarrollo Moche (Pérez de Arce, 1995: 43). En ella, al modo de una pareja sonora, dos músicos tocan lakitas de diferente composición, pues tienen las notas sucesivas de la escala mutuamente intercaladas, siendo necesaria su perfecta coordinación para alcanzar una musicalidad preciosa a sus oídos.

Aunque existe variabilidad en la cantidad de sopladores y algunas agrupaciones agregan más percusiones (timbaletas, sapito, cencerro, etc.), corresponden a un tipo de agrupación musical totalmente reconocible dentro de Arica y el resto del Norte Grande de Chile, llamado comúnmente: lakitas. Con algunas diferencias es posible encontrarlo, actualmente, en ciudades tan lejanas como La Serena, Valparaíso y Santiago (ubicadas aproximadamente dos mil kilómetros al Sur de Arica).

Estos aerófonos, usados con otras técnicas de interpretación, también son parte de agrupaciones tan distintas como bandas de carácter multinstrumental o compañías teatrales. Sin embargo, para mantener el oído concentrado en un sólo foco, usaremos a este universo como referente cuando sea pertinente.

En las comparsas de lakitas, la dicotomía fabricante/intérprete refiere a dos grupos de personas

\footnotetext{
${ }^{5}$ Para una revisión más acabada de la lakita dentro de la zona geográfica aquí abordada, se recomienda revisar Díaz y Mondaca (1998) y Fortunato (2010).

${ }^{6}$ Enfrentamiento sonoro entre conjuntos de lakitas. Cursivas en el original.
} 
que se intersectan. Por una parte, quienes las elaboran saben tocarlas y varios de ellos participan en conjuntos musicales. Por otra parte, todos los intérpretes conocen el proceso de fabricación de su instrumento y algunos también los construyen, aunque sea sólo con fines exploratorios o como relajo en sus momentos de ocio.

El origen de este tipo de aérofonos se encuentra "en algún lugar de los Andes Centrales hace más de 7.000 años" (Pérez de Arce, 1995: 43). Es posible seguir su traza en ciertas crónicas coloniales. Autores como Bernabé Cobo, Cristóbal de Molina, Felipe Guamán Poma de Ayala y Pedro Pizarro refieren su presencia en Los Andes (Focacci, 2000). En Arica, los instrumentos musicales más tempranos surgen junto a las momias Chinchorro, alrededor del año 2.200 AP, y las "zampoñas" o "antaras" son rastreables desde el dominio Tiwanaku (siglo IV dC) hasta la época Incaica (Focacci, 2000: 43-44). También existe evidencia de su presencia en otros soportes, como una tableta de rapé con "la figura de un hombre arrodillado" esculpida en su margen, tal "personaje está tocando una flauta de Pan, la cual sujeta con una mano, mientras en la otra tiene una hacha", hallada en contexto fúnebre, cerca de la desembocadura del valle de Azapa (Mostny, 1944: 140-141). Estamos frente a un objeto presente en Arica desde hace más de quinientos años. Un artefacto de preciosa ingeniería, por el agudo uso de materiales y formas que revela; y acabada arquitectura, por la delicada simpleza que luce en la disposición de sus volúmenes.

Hasta ya entrada la segunda mitad del siglo XX, las lakitas fueron fabricadas con caña, fibra vegetal bambúcea recolectada especialmente con dicho objetivo, de preferencia en los yungas fluviales de la actual Bolivia. "Dentro de las lakitas prehispánicas que se han conservado en la zona andina, encontramos ejemplares de cerámica, hueso, metal y caña" (Arancibia y Silva, 2010). Desde su aparición en la zona de Arica hasta nuestros días, han experimentado numerosas modificaciones (Silva, 2003; Arancibia y Silva, 2010), ellas pueden entenderse como de carácter sonoro, estético, social, práctico, entre otros. Todo esto permite levantar la siguiente hipótesis: el paso de caña a vinilo es un cambio tecnológico que se sostiene en una manera particular de pensar este instrumento y su musicalidad, la cual posee una larga data $y$, dicho cambio ha sido agenciado por sus propios fabricantes e intérpretes.

Este artículo busca dar respuesta a dos interrogantes, en torno al paso de la caña al vinilo, para el caso de las lakitas de Arica ¿Cómo sucedió este cambio tecnológico? ¿Cómo son entendidas, en la actualidad, las diferencias entre las lakitas de ambos materiales por sus cultores? Para luego abordar una de sus tantas continuidades sonoras, su capacidad de roncar, la cual caracteriza a un buen ejecutor 
y un buen instrumento.

El investigador José Luis Martínez propone que durante los siglos XVI y XVII, en aquellos campos donde tradicionalmente circulaban los "saberes andinos prehispánicos", éstos son, la oralidad, la visualidad y la dramatización, incluída la música entre ellos, se dieron "las respuestas a las políticas de control de la memoria y a los procesos de colonización de los imaginarios indígenas” (Martínez, 2005: 122). En ese sentido, nos situamos en un enfoque que considera la agencia y tenacidad de las poblaciones locales como eje del cambio y la continuidad cultural. El paso de cañas a vinilo en las lakitas de Arica no es una respuesta forzada ante la modernidad, ni un acto de supervivencia. Es fruto de una búsqueda musical, en el sentido amplio de la palabra "música". Es una expresión de autonomía y creatividad.

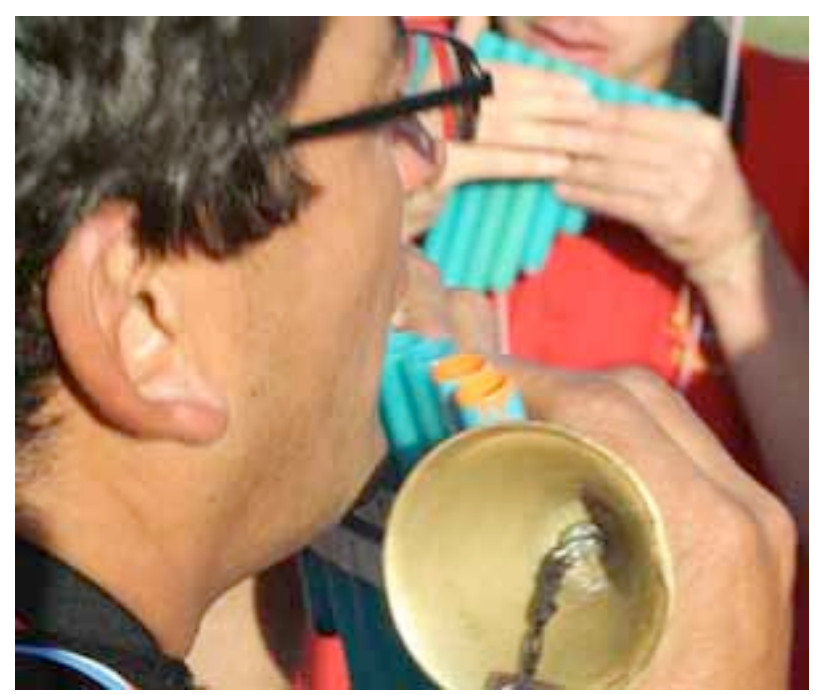

Caporal $^{7}$ de los Lakitas de la Manuel Cruz, durante la celebración de la Cruz de Mayo, en Alto Ramírez.

Se pueden observar en su instrumento tres tipos diferentes de PVC. El quinto tubo (de derecha a izquierda), de color verde agua, ya no se comercializa, pero es posible encontrarlo en oficinas salitreras de la pampa.

Los dos primeros, fueron fabricados para conducir cables eléctricos (naranja).

Han sido pintados de color celeste para homogeneizarlos con el resto de los ductos.

Los celestes han sido diseñados para entubar agua potable, son los más comunes entre las lakitas.

Fotografía de Gerardo Mora, mayo de 2009.

\footnotetext{
${ }^{7}$ Es posible reconocer fácilmente que se trata del caporal pues porta la campanilla. Con ella marca las entradas, salidas y todo movimiento, musical o corporal, que deba realizar la comparsa.
} 


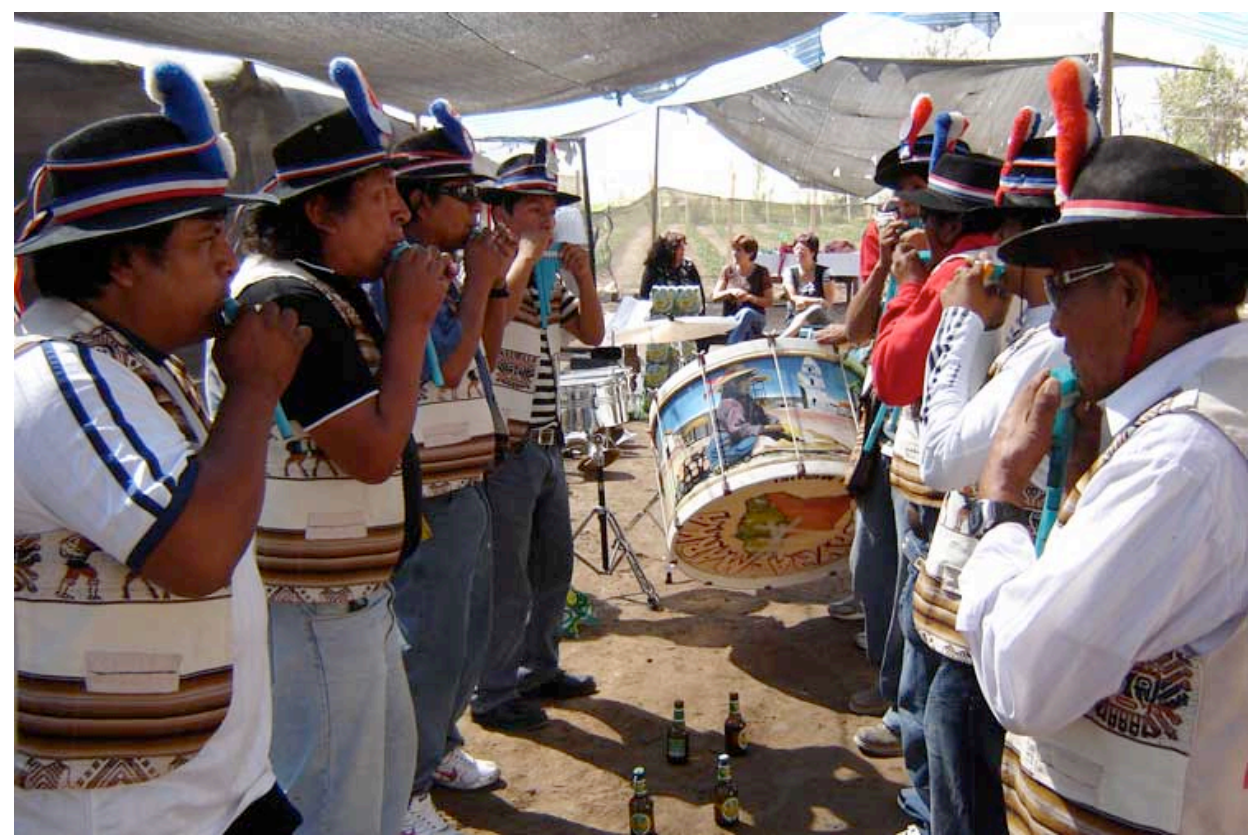

Huayna Marka en la celebración de la Cruz de Mayo, sector Pan de Azúcar, valle de Azapa.

Dos filas paralelas de sopladores enfrentados es la disposición espacial básica de toda comparsa, la cual puede cambiar, momentáneamente, según corresponda bailar y/o desplazarse.

Fotografía de Andrés Fortunato, mayo de 2009.

\section{Trayectoria y método}

Desde nuestras primeras conversaciones con músicos en Arica y el valle de Azapa, en el año 2004, pudimos constatar la relevancia del tema de la diferencia, y el paso, entre la caña y el PVC como material usado para fabricar lakitas. Ya en el verano del 2009 se comenzó a esclarecer, en nuestras anotaciones, la relevante participación de Martin Coya, connotado soplador a quien no conocíamos personalmente, en el primer momento de este cambio tecnológico. El desplazamiento de un sustrato vegetal a otro industrial, lo que alteró la manera de valorar, fabricar, manipular y pensar las lakitas en Arica.

En estas páginas, la lakita es abordada como parte de la tecnología en el sentido más amplio presente en los planteamientos de Langdon Winner (1979; 1985). Esto es, al instrumento musical como un aparato propiamente tal, vinculado al conjunto de actividades especializadas relacionadas con él y los dispositivos sociales técnicos presentes en su pensamiento y producción, sin olvidar sus aspectos politicos. El vuelco acá revisado abarca todo ese espectro, aunque las cotas de este artículo impidan abordarlo completamente. 
Cabe aquí resaltar la importancia del individuo en los procesos de producción y mantenimiento de las tradiciones musicales (Pelinski, 1997: [39]), por ello este estudio da un lugar central a la expresión y participación de los músicos en la historia, memoria y sonoridad de las lakitas. Esto, sin perder de vista la situación del intérprete musical, pues "la música es ejecutada por personas, en un contexto social guiado más por convenciones de naturaleza cultural que por un supuesto genio individual, asocial" (Finnegan, 2002: [30]). Además, la música es interpretada en, e interpreta a, un lugar.

Arica es una ciudad costera donde desembocan los valles de Lluta y Azapa. En el área geográfica donde se halla enclavada existe presencia humana desde hace 10.000 años, y ha recibido "varias migraciones con diferentes contenidos culturales" (Dauelsberg, 1992-1993: 11). Desde el siglo IV dC, ha estado bajo dominio Tiwanaku, de los Señoríos Regionales, los Incas y los españoles. Ya en el siglo pasado, como consecuencia de la Guerra del Salitre (1879-1883), deja de pertenecer al territorio peruano, para incorporarse oficialmente al chileno en el año 1929. A lo largo del siglo XX, en oleadas sucesivas, una numerosa población originaria de localidades del interior de Arica e Iquique, se traslada directamente a Arica o llega a ella luego de un periplo por la pampa salitrera ${ }^{8}$. De igual manera, grupos provenientes de Bolivia, Perú y Ecuador han migrado a esta ciudad, ya sea como parte de su camino hacia las capitales de Chile y Argentina, o para asentarse definitivamente allí.

Siempre atentos a cualquier antecedente que pudiera servirnos para nutrir nuestro trabajo en Arica, durante el invierno del año 2008, prestamos atención a una información que comenzó a circular entre antropólogos y afines. El material recogido y generado durante su trabajo de campo, por la doctora Maria Ester Grebe ${ }^{9}$, había sido entregado por su familia al Departamento de Antropología de la Universidad de Chile. La tentación era enorme. Nuestro apetito específico estaba en las imágenes y sonidos que pudieran guardar relación con la música en Arica y los pueblos del interior. Al consultarlo, dentro de una caja rotulada como "Músicos-Música", encontramos una diapositiva con las palabras "M. Coya y Lakas" escritas en su borde, a la cual no le dimos mayor relevancia dentro del material que reunimos.

Recién en enero del 2009 notamos que el "M. Coya" retratado por Grebe, podía ser el responsable de un potente giro entre las lakitas de Arica.

\footnotetext{
${ }^{8}$ Las migraciones de poblaciones del interior a la ciudad de Arica y sus condiciones de vida han sido ampliamente estudiadas. Al respecto se puede consultar Acevedo et al. (1970), Benavides (1993), González, H. (1996a, 1996b, 1997, 1999a, 1999b), González, H. et al. (1996), González, S. (2002), Grebe (1986), Gundermann (2001a, 2001b, 2002), Lecaros (1985), Tudela (2002) y van Kessel (1992a).

${ }^{9}$ De su trabajo se recomienda revisar Grebe $(1998,1985$ y otros).
} 


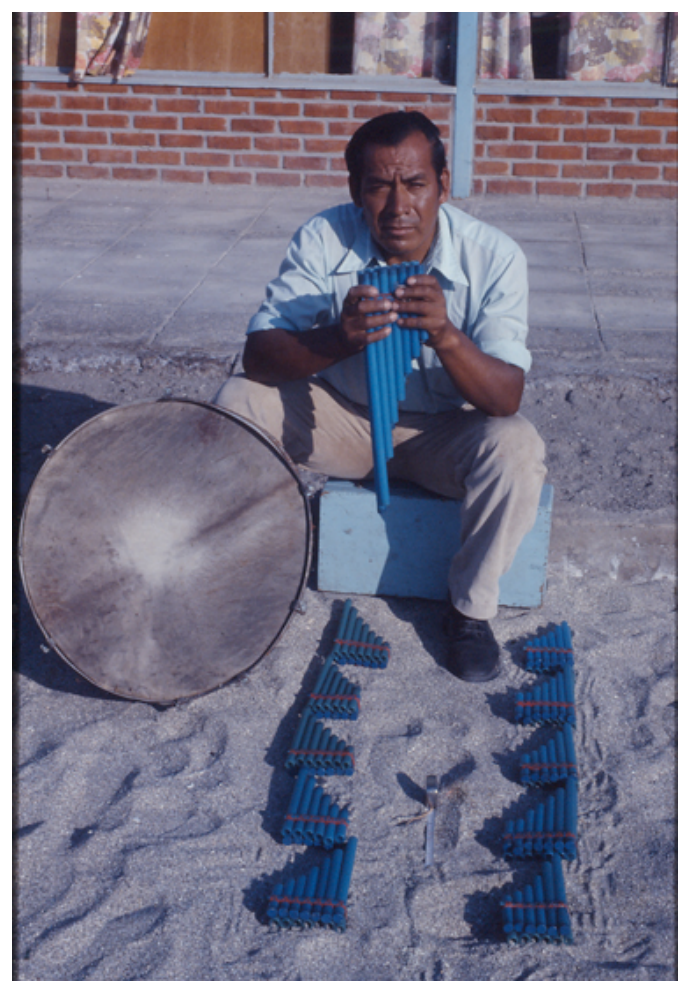

Fotografía hecha por Maria Ester Grebe.

Cortesía del Archivo Etnográfico Audiovisual,

Departamento de Antropología, Universidad de Chile.

Revelamos esa y otras imágenes con la intención de mostrárselas a Martín, para así provocar en él la evocación de recuerdos sobre esos tiempos. Este procedimiento no es nuevo dentro de la antropología. Uno de los primeros en reflexionar sobre el uso de fotografias al momento de hacer entrevistas en terreno, fue el fotógrafo e investigador James Collier (1957). Actualmente existe consenso en llamarle photo elicitation (Harper, 2002).

Las atractivos de la photo elicitation ${ }^{10}$ son múltiples. Primero, las fotografías pueden ser introducidas como un tópico de la conversación o en reemplazo de una pregunta; segundo, pueden reducir las diferencias de poder entre entrevistador y entrevistado; tercero, al responder a imágenes y no a palabras, el entrevistado puede incorporar antecedentes no previstos en el diseño de la entrevista (Montague, 2007: 64-65). Si bien, estas ventajas no son exclusivas de este procedimiento, nos dejamos empujar por la existencia de la mencionada fotografía para darle protagonismo en ese momento de nuestro trabajo. Era una manera de volcar a favor de nuestra labor ese inesperado hallazgo visual.

\footnotetext{
${ }^{10}$ Para conocer estudios que han hecho un uso más intenso y extenso de este procedimiento, se puede revisar Bruno y Samain (2007), Bunster (1978), Cabezas (2007), Calderola (1985), Pink (1997) junto a Radley y Taylor (2003).
} 
Con las fotografías ya listas, intentamos conseguir la dirección de Martín Coya. Nos fue imposible. En Arica, Abdón Cayo, un antiguo soplador, nos facilitó la dirección de su hermano Severo. Quien perteneció a la comparasa de Coya y vive en Huara, cerca de él.

Pensamos que un autómovil haría más agradable el viaje. Sergio Gómez, platillero de la comparsa de lakitas Huayna Marka, nos facilitó su vehículo. Con Alberto Olivares y César Borie partimos al alba, un día de febrero, camino a Huara, localidad ubicada a $230 \mathrm{kms}$. (por carretera) al Sur de Arica

Luego de desayunar en el cruce carretero, llegamos a casa de Severo Cayo. Conversamos distendidamente con él, afuera de su casa, sobre lakitas y fiestas. Al despedirnos nos dio buenas señales para ubicar y abordar a Martín Coya.

Tocamos a la puerta de su casa. Tardan en atendernos. Al rato se asoma un viejo alto con un sombrero ajado, quien nos hace dudar de si efectivamente se trata del domicilio de Martín Coya y de si es él, en persona. Nos invita a pasar con un gesto de curiosidad. Dentro de la habitación que da a la calle, hacia la derecha observamos una sala de estar, con un gran sillón enfrentado a un televisor; a la izquierda, un comedor marcado por la presencia de un mesa, en torno a la cual él ubica cuatro sillas para reunirnos.

Una vez acomodados, le presentamos en extenso detalle nuestra investigación en curso y pusimos algunas fotografias sobre la mesa. Las mira con sobrio desdén mientras aparta una. "A ese caballero, yo lo conozco". Se levanta para perderse por el largo pasillo que conducía al interior de la morada. Nos miramos mutuamente con desconcertada calma.

Al rato regresa con una pieza de refinada ingeniería musical, una lakita compuesta por tubos de múltiples de colores, vale decir, hecha con distintos tipos de tubos. Algunos muy antiguos, ya en desuso en obras de construcción; otros nuevos, de reciente ingreso al mercado ferretero.

Esa lakita es su historia personal. Allí están los recuerdos que pretendíamos desencadenar con una imagen. Se hizo evidente, "el sonido es memoria, aqui y en todas partes" (Feld, 1994: [9]). Él interpretó su biografía con ese instrumento.

Escuchamos en animado silencio el suave repicar de su exhalación remeciendo con seguras vibraciones cada tubo, no había vacilación ni esfuerzo en su gesto, sólo la dicha de quien goza plenamente de su actividad. Como toda persona realmente hábil en su oficio, se deleitaba tocando al tiempo que disfrutaba de nuestras expresiones de asombro y curiosidad. Algunas melodías nos parecían familiares; otras, plenamente novedosas e inquietantes. 


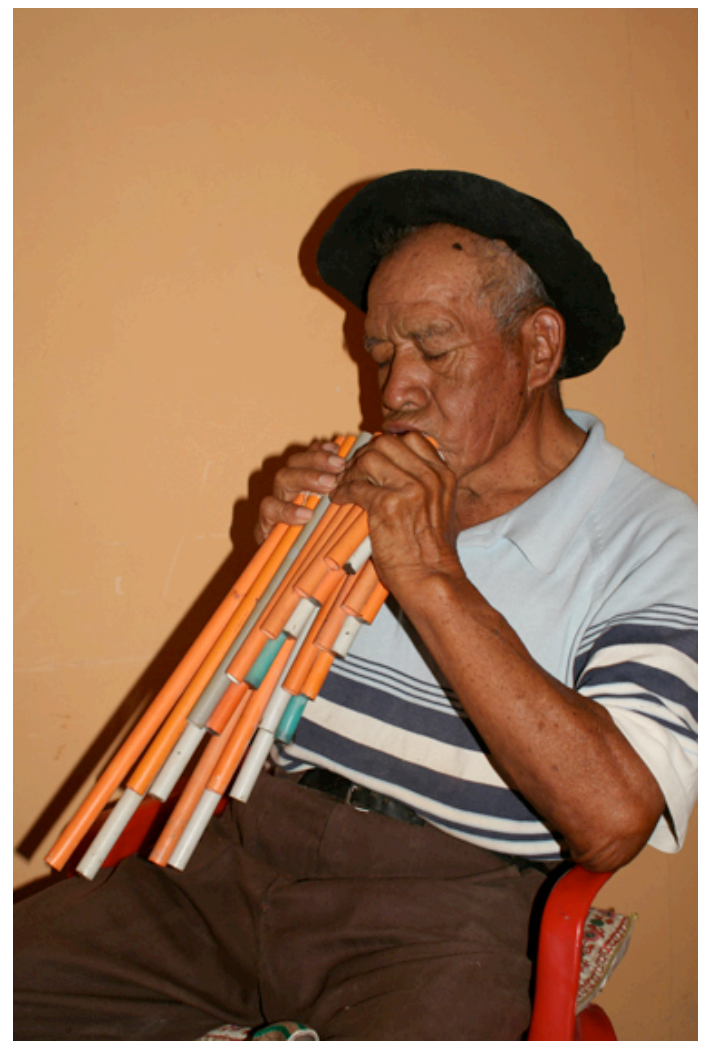

Martín Coya interpreta su memoria.

Fotografía de Gerardo Mora, febrero de 2009

Martin Coya es un lakita. Él no usa esta palabra para presentarse, lo hace a través de su instrumento, Aunque parece apropiado llamarlo con dicha expresión: lakita. Lo es porque fabrica, interpreta y piensa lakitas.

Conoció las lakitas a la edad de doce años, en su natal Jaiña, pequeño caserío que mira, desde la quebrada de Aroma, el imponente cerro Tatajachura, en las faldas del altiplano, al interior del puerto de Iquique. Prontamente aprendió a tocarlas. A los diecisiete años baja, como muchos, a la pampa salitrera. En la oficina de Santa Laura se une a un grupo de tocadores de su pueblo. Con ellos participó de fiestas religiosas en Chapiquiña, quebrada de Camiña. Una vez cerrada la oficina salitrera, en la década del sesenta, se trasladó a Arica, donde se reunió con varios músicos del interior. Los poblados de Sotoca, Chiapa, Zapahuira y otros dieron cuerpo a su comparsa. Al pasar los años fue participando en distintas agrupaciones, animando fiestas en el interior y en su nueva ciudad, con wayños, boleros, cumbias, cuecas y cha cha chá. Es hasta hoy, junto a varios músicos de Jaiña, un referente entre los lakitas de Arica.

Una vez que terminó de tocar, nos pusimos a conversar. Al poco rato apareció el tema que nos 
había llevado hasta su hogar, su encuentro con (o el invento de) las lakitas de plástico cuando ya vivía en Arica. Relato que reseñamos a continuación.

\section{Relato de Martín Coya}

Así que salíamos con el instrumento de caña pa'Camiña ${ }^{11}$. Pero pa'ir a la quebrada de Camiña, ya venían quebrados los instrumentos. Teníamos que comprar caña pa'reponerla, cambiarla. Ahí sucedió que mi señora viajó a Iquique. Tenía una prima en Iquique, casada con una persona del interior. Entonces encontró un instrumento de plástico arriba del velador.

- ¿Y este instrumento?

- Es del Pascual [Hidalgo]. Es que es de plástico.

- ¡Oh! ¿Por qué no me lo prestas?

- ¿Para qué?

- Porque Martín tiene problemas con el instrumento. Allá se les quiebra. A ver si se entusiasma a hacer de éstos mejor, más firmes.

Lo tomó, lo golpeó contra un macetero grande y no pasó nada poh ${ }^{12}$. Así que otra vez, que estábamos invitados pa'ir a otro pueblo, les dije yo.

- Mira, tengo esto que trajo mi señora ¿Cómo están? Hagamos uno de éstas.

- ¿Saldrá bueno?

- No sé, habrá que hacerlo, probarlo.

- Ya poh, hazlo no más, a las medidas.

Lo corté y las llevé completas. Eran todas de plástico negro esas, para instalación eléctrica. Así que ya, corté un juego completo ${ }^{13}$. Entonces ahí las probamos y todos tocamos. Entonces el más viejo, el de más edad de las personas, ése tocador viejo ya, de antiguo, fue a escuchar cómo sonaba el plástico. Nunca lo habíamos tocado, así que lo escuchó él.

\footnotetext{
${ }^{11}$ La expresión "pa" corresponde al apócope de la preposición "para".

12 Apócope de "pues".

${ }^{13}$ Un juego completo corresponde al total de lakitas que necesita una comparsa.
} 
- Está bueno, está bien, tiene sonido -dijo.

Entonces hicimos más. Compramos más tubos. Dije yo.

- Ahora están negros. Una cosa que puedo hacer es pintarlas, hacerlas azul, celeste. No salían estos plásticos celestes todavía ${ }^{14}$ ¿Las pinto celeste?

- Ya está, pintémoslas.

Empecé a pintar yo. Como trabajaba de vigilante pasaba rondando, ahí yo tenía tiempo demás pa’ hacer las cosas, así que las pinté y listo ¡Ya miércole! Salimos.

Nos fuimos a Camiña pa' la fiesta del Corpus Christi. Ahí llegamos, tocamos en la entrada y había un caballero que era el jefe. Era tocador también, antiguo. Él escuchó la voz, el sonido.

- Bah, tiene otro sonido ese instrumento ¿Qué será? -quedó pestañeando.

Cuando estábamos entrando con los instrumentos tocando, todos azules, le preguntaron.

- ¿Oye, han pintado las cañas éstos?

- Parece -dijo- no puede ser caña.

- No, sí es caña, están pintadas.

Así no podían salir de la duda. Ahí estaban "que eran de caña”, y los otros decían "es que no pueden ser caña". Así que entramos en la víspera, salimos y nos fuimos al local, al club a tocar allá, entonces uno quería saber: si es caña, sino es caña, vamos pa'allá donde los tocadores.

Estábamos tocando en el proscenio, llegó y dijo.

- Yo quiero saber si es caña o qué ¿Qué material es éste?

- Este es plástico -le dije.

- No, es caña -dijo el otro.

\footnotetext{
${ }^{14}$ Se refiere a las tuberías de PVC de color celeste, usadas comúnmente en la actualidad para conducir agua potable.
} 
- Ya poh, póngale la gamba ${ }^{15}$ encima, si es caña se va a quebrar ¿Y cuándo se va a quebrar el plástico? Si es caña yo te pago la caja de cerveza -dije-, y sino es caña me la pagas tú, se la ponemos a la comparsa ${ }^{16}$.

Y así que listo, ahí está ¡Ya, suelta la cajita no más! Pa’poner a la comparsa acá la cajita de cerveza.

- ¡Puta! ¿Y cómo hicieron este invento? -dijo.

- Bueno -dije yo- había que inventar algo porque las cañas todo el tiempo dan problemas, se quiebran, a veces anda uno curao $^{17}$, ya está medio malo ${ }^{18}$, se apoya así y se revienta altiro ${ }^{19}$ la caña, es muy delicada.

Y así que ya, listo, ya quedamos con eso. Y así fue el invento del instrumento plástico.

De esta manera finaliza el relato, más no la historia. Prontamente, otros músicos de Arica supieron apreciar las ventajas materiales comparativas, reseñadas en el relato anterior, del plástico en relación a la caña: mayor resistencia y durabilidad, menor costo y mejor accesibilidad. Sin que mediara, aparentemente, una reacción crítica, ya fuese con base en criterios estéticos o de otro tipo, ante la nueva sonoridad desplegada por las lakitas hechas con tubos de origen industrial y fines domicilarios.

La llegada (invención) de las lakitas de plástico en Arica, a fines de los años sesenta, es fruto de las redes de relaciones sociales de Martín Coya. Es su esposa quien viaja a Iquique para visitar a una prima, cuando ya se habían asentado en Arica. Ella, a su vez, estaba casada con Pascual Hidalgo, "una persona del interior", quien tenía sobre su velador la versión plástica de una lakita. Instrumento que ya había alcanzado bastante diseminación en las ciudades costeras del extremo Norte de Chile.

Martín, su señora y sus primos políticos, son originarios de poblados ubicados al interior de Arica e Iquique y se trasladaron hacia estas urbes, a mediados del siglo XX. De acuerdo al modelo de la "regionalización de la sociedad aymara" ${ }^{20}$, este tipo de movilidad no corresponde a un simple

\footnotetext{
${ }^{15}$ Expresión usada para referirse al pie o al calzado.

${ }^{16}$ Una comparsa es un conjunto o agrupación de músicos y/o bailarines.

17 "Curao" viene de la palabra "curado" (participio del verbo "curar"), expresión que indica un grado notorio de borrachera.

${ }^{18}$ Estar o andar "medio malo" alude a los efectos perniciosos de la ingesta de bebidas alcohólicas.

19 "Altiro" significa "de inmediato".

${ }^{20}$ Cursivas en el original.
} 
proceso migración ni de una ruptura, sino a "la formación de un sistema de relaciones que se despliega en uno y otro sentido, tanto en el nivel de los individuos-hogares, como en el colectivo, entre las localidades andinas y las áreas de migración" (Gundermann, 2001a: 104). Cuando esa lakita plástica primigenia se desplaza desde Iquique a Arica, entre primos y matrimonios, es un ejemplo de cooperación intrafamiliar que revela la continuidad de tipos de relaciones institucionalizadas preexistentes; y los viajes de la comparsa de Martín Coya, formada por músicos nacidos en diversas localidades, a la quebrada de Camiña, corresponden a "nuevas formas de relación que se establecen entre migrantes en las ciudades y de los migrantes con las localidades de origen" (Gundermann, 2001a: 105). Las lakitas nos proponen que su existencia y dinamismo se sostienen en formas sociales que guardan continuidad con otras de orígenes tan antiguos como sus sonidos.

\section{De cañas y vinilos}

En la memoria de los lakitas de Arica, quien nos narró el relato anterior ocupa un lugar especial. “El caballero este, Martín Coya, como le digo, él fue el que inventó el plástico” [Osvaldo Tobar]. Y se sitúa el evento hace cuarenta años atrás.

Yo pienso que aquí en Arica, debe haber sido a finales de los sesenta o principios de los setenta. Así debe haber sido. Porque al venirse los compadres de Jaiña acá, no creo que hayan estado tocando con caña. Tuvieron que buscar la manera de tocar zampoña, pero buscar un tubo adecuado, y ahí pillaron éste. [Héctor Mollo]

Un aspecto que merece revisión, es el grado de incidencia que pudo haber tenido el Golpe Militar en este cambio tecnológico. Bajo la Dictadura (1973-1990), la llamada música "andina" o "nortina", fue objeto de la represión ejercida de manera no oficial por quienes detentaban el poder gubernamental (Jordán, 2009: 81). Esto, en términos concretos, afectó la libertad e integridad de los miembros de agrupaciones musicales que contaban con quenas, charangos, tarkas, etc. dentro de su formato instrumental. Ellos se vieron a medio camino entre presentaciones clandestinas y la resistencia cultural, aunque algunos no tuvieran parte activa en la oposición política al gobierno.

Sin desconocer la vileza de estos hechos, existe una anécdota, que hemos escuchado en terreno y puede funcionar como provocación de futuras investigaciones. 


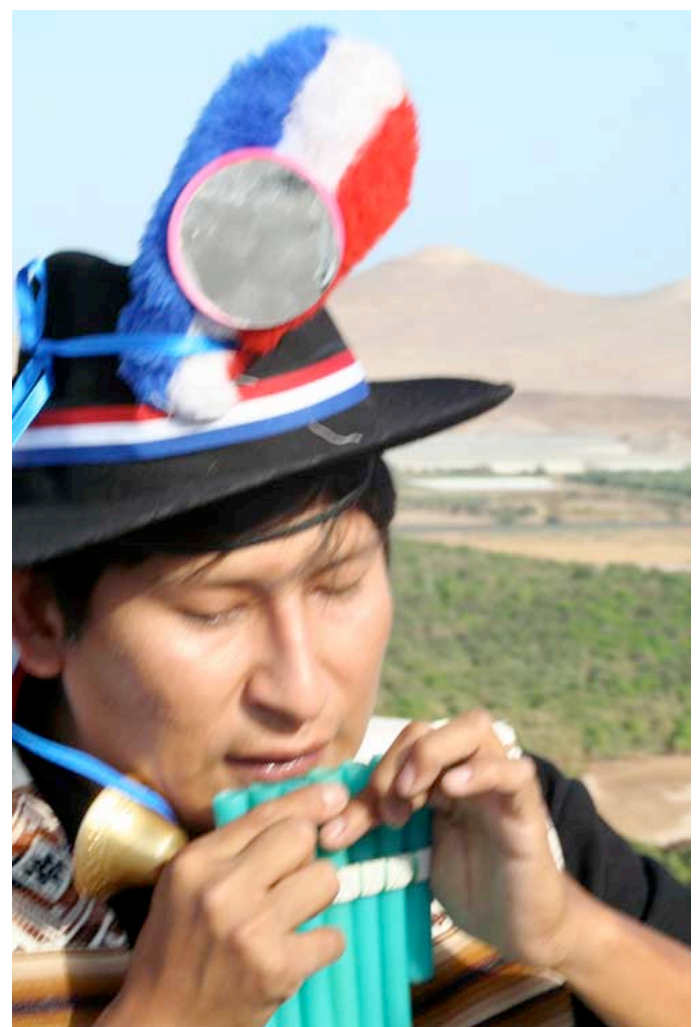

El sombrero de un lakita se reconoce por el tricolor de sus cintas y penacho, junto al espejo circular.

Fotografía de Gerardo Mora, mayo de 2009.

Antiguamente, los intérpretes de lakitas usaban sombreros con un penacho hecho de plumas naturales $^{21}$, de varios colores. Dicen que un día, el entonces presidente de facto Augusto Pinochet, visitó la ZOFRI (Zona Franca de Iquique). En esa ocasión se presentó una comparsa. Él miró con particular atención los penachos y dictaminó: “háganse esa hueá ${ }^{22}$, pero con el tricolor chileno”. Desde entonces los penachos se hicieron con trozos de felpa, que semejan plumas, en blanco, azul y rojo.

A veces este relato, con algunos matices, tiene como protagonista a Carlos Ibañez del Campo, presidente de Chile en dos períodos, 1927-1931 y 1952-1958, quien es recordado en Arica por la implementación de sus planes de mejoramiento, en particular, la Junta de Adelanto.

Más allá de la veracidad de estas narraciones, lo interesante es que existen y circulan como parte de la memoria de los lakitas. Además, aquellos primeros instrumentos fabricados con tubos de origen industrial tenían por amarras cintas plásticas tricolores y los penachos de sus intérpretes lucían

\footnotetext{
${ }^{21}$ En tiempos coloniales, el sacerdote jesuíta Bernabé Cobo, señala sobre cierto baile, dentro una celebración realizada por los Incas, lo siguiente: "[...] entraban en él, vestidos de unas camisetas coloradas largas hasta los pies, y unas diademas de plumas en las cabezas, tañendo unos cañutos pequeños y grandes puestos a modo de cañones de órganos" (1956 [1653], II Lib. XIII, Cap. XXIX:218 en Focacci, 2000:40). Las cursivas son nuestras.

${ }^{22}$ Apócope de "huevada".
} 
los colores de la bandera ${ }^{23}$ ¿Es posible plantear la existencia de una política de nacionalización, ejercida desde el Estado, en la estética de las lakitas y sus intérpretes? Queda planteada la interrogante.

Para mediados de la década del setenta, la caña estaba prácticamente fuera de las comparsas de lakitas. Su uso, al menos en Arica, pasó a ser privilegio de conjuntos artísticos de exhibición ${ }^{24}$. Agrupaciones que realizaban presentaciones en eventos artísticos. Las cuales, movidos con fines folklóricos, buscaban a través de la caña y otros elementos, realizar una labor de rescate cultural.

En contraste, algunos fabricantes de lakitas colaboraron con el desmantelamiento de ciertas oficinas salitreras en la pampa, que disponían de tuberías eléctricas que ahora les eran peculiarmente atractivas. Aún hoy estos lugares son prospectados. De hecho, "todavía quedan de esas verde agua en La Tirana ${ }^{25 "}$ [Miguel Capa].

Con el correr de los años, las técnicas de fabricación mantuvieron su aguda simpleza, aunque los tubos de plástico presentaban sucesivas innovaciones industriales y aumentaba la habilidad de los fabricantes de lakitas para dominar este material. No obstante, hace años se incorporaron afinadores digitales, adhesivos industriales, etc. Cabe señalar que el uso de trozos de discos de vinilo, en los tapones de los tubos, surge en la década del ochenta. Probablemente, gracias a la masificación del casete como formato de reproducción de sonido. Por último, una inquietud aún abierta ¿Cuáles son las diferencias, entre caña y vinilo, presentes en la fabricación de las lakitas?

La caña pasó rápidamente a cumplir un nuevo rol entre las comparsas de lakitas. Ya no sería el componente básico de sus instrumentos; sino, un insumo de su memoria. Esa memoria que no aspira a ser verosímil, más bien busca instaurar un pasado, modelar sus formas y se fusiona con él, guiada por el desorden de la pasión, las emociones y los afectos (Candau, 1998: 127).

Para empezar, existen diferencias entre las cañas. Hay una considerada "legítima", "autóctona" o "legal". Es nativa de los yungas fluviales o ceja de selva de la actual Bolivia. Por lo mismo, algunas veces, el material o los propios instrumentos son encargados o traídos desde allá. Díaz y Mondaca (1998: 85) proponen que este flujo existiría desde el período Tiwanaku.

Sino se puede acceder a ella, es recolectada en el valle de Lluta. Como señala Adolfo Aika, "mi padre aprende a tocar esta zampoña [de caña], pero lo aprende a tocar con zampoña hecha en Lluta, una caña muy dura, no de Bolivia, muy dura". Se trata de un caso especial de lakitas, pues poseen doble

\footnotetext{
${ }^{23}$ Una revisión del material fotográfico podría entregar mayores antecedentes a esta discusión.

${ }^{24}$ Apuntamos aquí a Llarani, Peregrinos del Norte, Cultores Huayna, Intin Wawanakapa y otros.

${ }^{25}$ Poblado pampino donde se realiza la fiesta religiosa de mayor convocatoria en el Norte Grande Chile, que está dedicada a la Virgen del Carmen, patrona del país.
} 
hilera, así las diferencias sonoras son aún más distinguibles. La preferencia por las cañas bolivianas se sustenta en sus particulares espesor y rigidez.

Fueron hechas en Lluta, pero para ensayar. Los días antes de venirse a Las Peñas, alguien trajo de Bolivia zampoñas más delgadas. Él decía que sonaban así, blanditas, era una expresión que tenía, blandita. No dura como la de Lluta, que es gruesa. Entonces dice que al soplar sonaba solito. Además que ya se habían acostumbrado a hacer sonar las cañas duras ¿No? Entonces al traer de Bolivia, con esas fueron, eran blanditas y eran grandes -dice- eran grandes, pero ya estaban acostumbrados. La caña más blandita suena más, resuena más. Tiene un sonido más rico, digamos, más armonioso. Porque son cañas apropiadas, son delgadas. Resuena, vibra más. Por eso trajeron de Bolivia, ahí aprendió ya mi padre y no dejó de tocar hasta como dos años antes de fallecer. [Adolfo Aika]

Así Adolfo recuerda las enseñanzas de su padre Hilario Aika, figura clave en la fiesta de Las Peñas $^{26}$. Quien le indica que, a materiales diferentes, corresponden sonoridades diversas. La caña lluteña es más "gruesa" y “dura”, en comparación a la nativa de los yungas. Ésta, más "delgada” y "blanda", tiene un comportamiento mecánico distinto al desplegado por su contraparte, "resuena, vibra más". Además, facilita la ejecución del instrumento, pues "al soplar sonaba solito", y entrega mejores resultados, "un sonido más rico" y "más armonioso". Hilario, en el relato de su propia propedéutica, entrega a su hijo los criterios necesarios para reconocer una caña óptima, por ende, un instrumento musical ventajoso. Esto le dará más posibilidades de convertirse en un buen intérprete y así, ser capaz de brindar las mejores ofrendas musicales a la Virgen de Las Peñas.

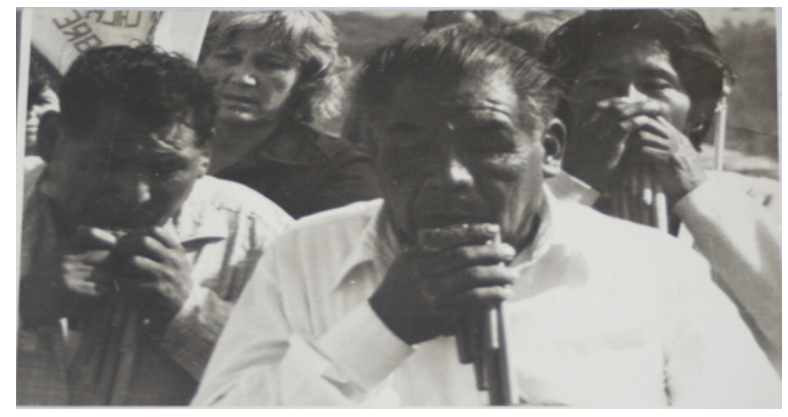

Hilario Aika en celebración a la Virgen de Las Peñas.

Fotografía facilitada por Adolfo Aika.

Pero Hilario Aika fallece a mediados de los setenta, no alcanza a experimentar plenamente la radical hegemonización del plástico entre las lakitas. Sin embargo, la estructura analítica, donde él y sus pares fundamentaban la evaluación de un instrumento y un soplador, seguirá vigente.

\footnotetext{
${ }^{26}$ Sobre su participación en el culto a la Virgen de Las Peñas ver Borie y Mora (2010) y van Kessel (1992b).
} 
Alberto Díaz y Carlos Mondaca señalan que los lakitas de Tarapacá ${ }^{27}$ sostuvieron el paso de la caña al PVC, en consideración a las siguientes ventajas de este último: abundancia en contexto urbano, bajo precio, carencia de porosidad, sonido inalterable ante cambios de temperatura, no se quiebra fácilmente, da un sonido de mayor volumen y no es necesario encargarlo a Bolivia (Díaz y Mondaca, 1998: 86).

Si bien, tal como se revisará más adelante, el aspecto sonoro es discutible desde la percepción expresada por los propios músicos. Hay coincidencias con el estudio citado. Se trata un cambio basado en criterios prácticos, cimentados fundamentalmente en las características económicas (accesibilidad) y físicas (estabilidad, resistencia y ductilidad) de cada material.

Las cañas, más aún las bolivianas, son difíciles de obtener hoy en Arica. Se trata de un bien escaso y costoso. Por el contrario, hasta mediados del siglo $\mathrm{XX}$, algunos poblados del interior tenían estrecho contacto comercial con Bolivia. Lo que facilitaba el acceso a sus productos.

Nosotros ahí, en el pueblo de $\mathrm{Chiapa}^{28}$, teníamos personas que eran comerciantes, que trabajaban con Bolivia. Entonces ellos mismos, que sabían tocar la zampoña, traían la pura caña no más ${ }^{29}$. Entonces había un caballero que nos hacía la zampoña. [Abdón Cayo]

Se enriquece con este testimonio un punto señalado al inicio de este artículo, no sólo fabricantes e intérpretes saben tocar este instrumento, también quienes comercializan sus componentes poseen esta habilidad. Así, puede ser que no sólo materia prima cruzara la cordillera de Los Andes. Tal vez ritmos, repertorios, modalidades de ejecución, etc. pudieron viajar junto a las cañas desde los yungas. La rigidización de las fronteras nacionales ha alterado las modalidades y contenidos de este flujo.

Actualmente, los tubos de plásticos son fáciles de conseguir. Es posible recolectarlos en construcciones antiguas o deshabitadas. Dado que duran alrededor de setenta años sin necesidad de mantenimiento alguno, es común que sobrevivan intactos al abandono. También se pueden adquirir a un bajo precio en el mercado ferretero ${ }^{30}$.

A esta gran ventaja se deben sumar las características físicas propias del Policloruro de Vinilo. Se trata de un material de baja densidad, esto lo hace ser muy liviano, tal como las cañas vegetales; de

\footnotetext{
${ }^{27}$ Estos investigadores desarrollaron la investigación aquí citada antes de la creación de la región de Arica y Parinacota, con lo cual al hablar de Tarapacá, como lugar de estudio, abarcan lo que hoy corresponde a la nueva región y la actual región de Tarapacá. Toda esta zona comprende el extremo Norte de Chile.

${ }^{28}$ Localidad cercana a Jaiña, quebrada de Aroma.

29 “...traían la pura caña no más" quiere decir “...sólo traían la caña”.

${ }^{30} \mathrm{Su}$ valor bordea, en promedio, los 200 pesos chilenos por metro lineal, que corresponden aproximadamente 0,7 reales, al momento de presentar este artículo.
} 
excelente resistencia mecánica, es decir, soporta la acción de fuerzas aplicadas directamente sin romperse; y de gran resistencia al impacto, pues absorbe la energía de buena manera durante las cargas de choque. Si bien posee otras propiedades que le hacen ser apreciado industrialmente, se han consignado sólo aquellas que sustentan los elementos comparativos señalados por los músicos al ponerlo en relación con la caña.

La fragilidad y delicadeza de los instrumentos hechos con caña son recordadas como dificultades y fuentes de restricciones. Por lo tanto, un punto importante de contraste entre las lakitas de caña y las de PVC, está en el cuidado que requieren. Si las primeras no son transportadas y tratadas con extremo cuidado o se permite su resequedad, corren el riesgo de resquebrajarse.

Ahora no poh, la de plástico es más fácil. Antes no, las cañas así van bajando [su diámetro], así como el dedo. Éste es más grueso, y éste, y éste otro, así. Pero había que cuidarla. Ya terminando de tocar uno, había que guardarla. Había que hacerle su ceremonia y guardarla en un manto bien, cosa que no le entre mucho el aire, si no se reventaban. Hoy día no, las de plástico uno puede dejarlas tal como se quedaron, ponerle cualquiera cosa arriba de la mesa no más y listo. Ahí lo va dejando ahí y no le pasa nada poh.

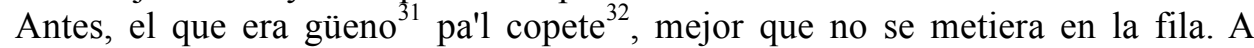
veces de repente uno, yo mismo. Me pasó a mi que yo quebré uno por completo. Me tropecé, no estaba curao, me tropecé y me ganó el cuerpo, lo quebré completo, quede sin tocar después poh, eso es lo que pasa. Hoy día no poh, el plástico se puede caer, tiene que ser mucho pa'quebrarlo.

[Abdón Cayo]

Lo mejor es la caña. Pero usted tiene que saber tratarla. Ésta [la de PVC] es más limpia, porque en cualquier momento usted la lava y no pasa nada. La caña no. Usted la tiene que lavar una vez que terminó todo de tocar. Porque como le digo yo, se seca la caña y se parte, se raja. Nosotros hemos estado años atrás tocando con pura caña y teníamos ese problema, que todo el tiempo se rompían las cañas. Después que entró el plástico ahí ya no, se destapa, uno le raspa un poquito ya pega, y a seguir tocando altiro. [Osvaldo Tobar]

La resistencia de las lakitas de PVC hace posible prescindir de ciertos cuidados precisados por las de caña, como "su ceremonia", el "manto" que protege del aire y el lavado. El plástico es un material tan noble que permite el descuido: ya no es necesario guardarlas, es posible usarlas en estado de intemperancia y se les puede reparar de manera presurosa.

Por otra parte, la caña estuvo presente en los primeros encuentros entre los sopladores más viejos y las lakitas. Les evoca su infancia y pueblos de origen.

Yo aprendí a tocar a la edad de ocho años, con caña no más poh. Éramos de la escuela, así jugando hacíamos nosotros nuestras cañas. Hacíamos a veces

\footnotetext{
${ }^{31}$ La expresión "güeno" corresponde a "bueno", en este caso, "con una tendencia favorable hacia".

${ }^{32}$ La voz "copete" es el término genérico usado para designar a cualquier bebida alcohólica.
} 
nosotros con los niños y ahí aprendíamos. Ya sabíamos algo por lo menos, ya nos integrábamos al conjunto. [Abdón Cayo]

En Belén, tocaba sikura con mi abuelo, también laka de caña. Ahí nosotros inventamos zampoñitas, con residentes bolivianos, como pa' meter bulla, tocábamos hasta cierta hora no más. [Eduardo Choque]

En palabras del geógrafo Ray Hudson, "la música tiene la habilidad de conjurar poderosas imágenes de un lugar, sentimientos de profundo arraigo a un lugar” (Hudson, 2006: 626). Abdón y Eduardo escuchan en el sonido de la caña -y no sólo en su sonido- a Chiapa y Belén. En situaciones de cambio y movilidad, la producción del lugar a menudo es intensificada ${ }^{33}$ (Cohen, 1995: 443). La música conjura, no sólo desde su sonoridad, sino tambien desde la materialidad y arquitectura del instrumento, la manera de fabricarlo y tocarlo, junto a los vínculos sociales relacionados con él. Se trata entonces de un hechizo tecnológico, siguiendo la idea de tecnología planteada anteriormente. En las lakitas de caña, Abdón y Eduardo escuchan a sus pueblos de origen, su infancia, sus amigos de la niñez, sus abuelos, su escuela, su primer conjunto, etc. "El lugar, para muchas comunidades migrantes, es algo construído a través de la música con una intensidad no encontrada en ningún otro lugar de sus vidas sociales" (Stokes, 1994: 114 en Cohen, 1995: 443). Para el caso estudiado, se puede plantear que la música da intensidad a sus vidas sociales, a la vez que construye el lugar donde se despliega. Estas comparsas tocan en Arica y en los poblados del interior, interpretan esos lugares.

\section{Hacerla roncar}

Encontramos interesantes concordancias, al cotejar los resultados de nuestra investigación, con aquélla desarrollada sobre el "sonido rajado"34, por el musicólogo José Pérez de Arce y su equipo. Entre los chinos de Los Andes Sur existe una idea muy precisa, en términos estéticos, de lo que constituye el buen sonido de sus pifilcas, y de que para conseguirlo se requiere la conjunción de un buen instrumento (un dispositivo de sonido especialmente diseñado) y un buen instrumentista (una técnica específica para hacerlo sonar) (Pérez de Arce, 1998). En términos generales, observamos lo mismo para el caso de los lakitas en Arica.

No obstante, ante la contraposición entre lakitas de PVC y de caña, no existe consenso entre los

\footnotetext{
${ }^{33}$ Queda abierta la discusión en torno a como entre los lakitas, según lo plantea Sara Cohen para el caso de los migrantes judios en el puerto de Liverpool, la experiencia de la migración o el viaje pudieran estar expresadas a través de códigos semióticos culturales específicos en estructuras y sonidos musicales (Cohen, 1995:443).

${ }^{34}$ Al respecto se sugiere consultar Mercado (1995-1996) y Pérez de Arce (1997; 1998; 2000).
} 
músicos respecto de cual posee las mejores cualidades sonoras de acuerdo a sus oídos y criterios de belleza. Sólo se ha resuelto que presentan sonoridades distintas.

Pero ¿A qué nos referimos cuando discutimos la sonoridad de una lakita? El antropólogo Gregory Bateson, con palabras simples plantea un espeluznante dilema humano, "el nombre no es la cosa nombrada" (Bateson, 1991: 221). Es decir, la expresión “el sonido de una lakita”, no es el sonido de una lakita en sí.

Para sortear este dilema, revisaremos la distinción entre son propre (sonido propiamente tal ${ }^{35}$ ) y son vécu (sonido vivido) elaborada por Jean-François Augoyard (2001). De acuerdo a él, la unidad de una situación sonora concreta se realiza en la vivencia de los auditores. Ni las medidas físicas, ni los registros, ni las descripciones, ni las observaciones etnográficas son suficientes para dar cuenta de ella. El son propre es físicamente mesurable y registrable, no obstante, los individuos lo interpretan a partir de sus caracteristicas personales, códigos colectivos e instancias simbólicas presentes en la situación sonora. Cada oyente percibe y recuerda un son vécu, que se expresa en sus actitudes y observaciones personales (Augoyard, 2001: 129).

En consecuencia, cuando revisamos los testimonios de los sopladores, no encontramos allí, de manera directa, antecedentes sobre el sonido de las lakitas propiamente tal, sino más bien de como ellos lo han experienciado e interpretado. Cuando un músico, un especialista en su arte, señala que una lakita de PVC tiene un sonido distinto al emitido por una de caña, sin desconocer que hay una diferencia en el son propre, se trata de una comparación del son vécu.

Ahora es PVC, plástico que le llaman, y ése da otro sonido. Yo que me crié en esa zampoña antigua, que siempre uno extraña. Ya casi no hay conjunto que toque con zampoña de caña. Ya no hay ya, porque es muy delicado, es caro traer de Bolivia. [Adolfo Aika]

Se retoman aquí las sensaciones de nostalgia y escasez asociadas a la caña. Aquí Adolfo no presenta un análisis comparativo de ambas sonoridades. Sólo apunta que el nuevo material "da otro sonido", vale decir, entrega una vivencia distinta.

La diferencia es que la caña da, un poquito, un sonido más claro, y el plástico un poquito medio bajo así, más gordo, pero casi yo lo encuentro igual no más. Son iguales de tocar, un tocador toca no más. Si el instrumento estando bien afinadito, sale sólo el sonido. [Martín Coya]

Martín establece que las diferencias son pequeñas, la lakita de caña daría un "sonido más claro"

\footnotetext{
${ }^{35}$ Se acoge la traducción de estos conceptos presentada por la etnógrafa Soledad Martínez (2010).
} 
y la de plástico uno "medio bajo", "más gordo". Sin embargo, señala que el contraste es menor o inapreciable. La clave está en la resolución que dan el intérprete y el instrumento, pues ambas -caña y PVC- "son iguales de tocar", responden a una misma técnica de ejecución. "Un tocador toca no más". En otras palabras, quien domina la habilidad de interpretar las lakitas, lo hará sin que la materialidad de éstas incida en su desempeño. Además, "si el instrumento estando bien afinadito, sale solo el sonido". Por lo tanto, si el dispositivo fue fabricado, mantenido y ajustado de la manera apropiada, facilitará su ejecución al no demandar esfuerzo alguno por parte del soplador.

La de caña es mejor, más sonora. La de caña se siente de más lejos, la de plástico no, hasta por ahí no más. Igual que el bombo de hoy día. Al bombo le han colocando mucho plástico ahora. El de cuero legitimo, ese se siente más lejos, esa es la diferencia también poh. Y las cajas antes no, no tenían plásticos, eran puro cuero también. [Abdón Cayo]

Adbón abre un nuevo campo de apreciación. El volumen entregado por el instrumento, es también una variable a considerar en la situación sonora. Este músico considera deficiente la intensidad de sonido entregada por el plástico. Lo cual incluso habría afectado el despliegue sonoro de dos instrumentos que acompañan a las lakitas: el bombo y la caja.

El plástico no es que tenga buen sonido, porque éstas son como sordas. Se toca acá no más y se escucha acá no más. Sin embargo la caña no, la caña el viento se lleva el sonido y se expande. No sé si ustedes han captado la diferencia. [Osvaldo Tobar]

Osvaldo coincide con Abdón. El sonido emitido por la caña posee propiedades expansivas, “el viento se lleva el sonido", por el contrario, el plástico tiene un carácter implosivo, su sonoridad es incapaz de alejarse ostensiblemente de la fuente emisora. Esto es una diferencia clara para Osvaldo y es tajante en su juicio, "el plástico no es que tenga buen sonido".

Se puede desprender de sus palabras, y a la luz de los antecedentes ya expuestos, que el plástico no ha sido elegido como material preferente por sus propiedades sonoras.

Hay diferencia entre PVC y la caña, la caña es un sonido más autóctono. Es más bonito, pero es más bajo, uno lo toca y lo toca más bajo. Es como para escucharlo acá, en el momento. En cambio, el PVC es más fuerte, es como para que se sienta más fuerte. [Miguel Capa]

Ya entramos en tierra de desacuerdos. Para Miguel la diferencia estaría dada por el carácter "autóctono" brindado por la caña a la situación sonora. Como ya vimos, se trata de su vínculo evocativo con tiempos y lugares del interior. Trae nostalgias y anhelos a sus oídos. El PVC en cambio, 
si bien no posee esta propiedad, es capaz de entregar una intensidad a las ondas sonoras que les permite alcanzar un espacio-tiempo distante del emisor. $\mathrm{Su}$ alto volumen moviliza al sonido hacia instancias remotas y, tomando las palabras de Miguel, ya no es sólo "para escucharlo acá, en el momento", sino que puede ir más allá de este lugar y este instante. La propia vivencia sonora se expande.

La de caña suena mejor, porque con el mismo calor como que levanta más. Y el PVC también es seco, pero como que se apaga un poco, hay que emboquillarla bien no más, pero la de caña es mejor, levanta más, da más sonido, más fuerte. [Basilio Coya]

Prosigue la discusión. A oídos de Basilio la caña "suena mejor", incluso a una misma temperatura logra dar "más sonido, más fuerte". La deficiencia del PVC puede ser superada por un buen intérprete que sea capaz de "emboquillarla bien no más". Pero su evaluación es clara, "la de caña es mejor", y lo es por la intensidad de su sonido.

Bueno, indudablemente que hay una enorme diferencia. Me gusta más el de caña, es más armonioso, más cálido el sonido. Es algo que al escuchar tiene un sonido ¡Ah! Es muy bonito, muy hermoso. El de PVC, siempre lo he encontrado un poco frío. Suena fuerte sí, muy fuerte. Pero lo he encontrado siempre un poco frío. El de caña no, porque yo nací, me acostumbré con la caña, aprendí con eso. [Adolfo Aika]

Adolfo retoma la palabra para señalar ciertos contrastes. Las virtudes sonoras de la caña son armonía, calidez y belleza. El plástico sólo destaca por su fuerza y es "un poco frio". Con una mirada reflexiva, señala que sus apreciaciones están mediadas por su biografía. Él nació y aprendió con caña.

Tocar caña es más fácil todavía ¿En qué sentido? Que el plástico es duro, cuesta. Y la caña tú le pones la boca así ¡Pum! Rico. Hay que hacer el sonido no más. No rajarla, no, no. Al plástico hay que sacarle el sonido, cuesta, cuesta más ¡Pah! Cuesta más. Pero la caña tú la tomas así ¡Fsss! y suena ¡Dum! Suena ¡Dum, dum! Suena bonito. El plástico no poh, tienes que hacerle fuerte ¡Pum! Tienes que hacerle fuerte. [Johnny Medina]

El joven Johnny centra las diferencias en las exigencias hechas al intérprete por parte del instrumento, áquellas que él mismo ha debido afrontar. Ejecutar una lakita de caña es "más fácil” pues sólo basta con emboquillarla. A la inversa, "el plástico es duro", tal como las cañas lluteñas comparadas con aquéllas de los yungas. Por ello, es necesario "hacerle fuerte" y este esfuerzo cansa al soplador, limita sus capacidades de ejecución y compromete los resultados de su interpretación. Ya sea que esté tocando por devoción y/o por contrato, no podrá estar en su mejor nivel, pues no dispone de un buen instrumento.

El PVC delgado no te ronca, se te apaga. Cuando hay calor, ronca bueno. El 
interior [precordillera y cordillera] es frío, no ronca. Por eso uno compra un plástico más grueso. Un juego de zampoñas delgado es rico en el verano acá [cerca de la costa]. Las zampoñas celestes y naranjas, son gruesas, rocan en el interior. Las de caña siempre roncan, pero se rompen fácilmente. Las de caña suenan más rico. [Alfredo García]

Alfredo pone sobre la mesa un aspecto clave que caracteriza el buen sonido vivido de una lakita: el roncar, el cual devela una cualidad impajaritable de todo buen intérprete: tener la habilidad de hacerla roncar. Existen otras "formas de soplido, y técnicas para interpretar", por ejemplo, picar y raspar, también hay resultados inapropiados e indeseables en la ejecución, como chancar y chiflar (Fortunato, 2010), pero acá nos centraremos en la que se escucha como la más apreciada de todas las virtudes. Diaz y Mondaca señalan que en la ejecución de las lakitas se busca un sonido "de vibrato y ronquido" (1998: 80). Si lo anterior estuviera comprometido con este cambio tecnológico, se hace necesario analizar el nuevo material.

Alfredo señala un factor crucial en la relación entre los materiales y su sonoridad, ya insinuado por Basilio Coya, la variabilidad de su comportamiento según la temperatura del ambiente donde se encuentran.

En su tesis sobre este aerófono, Godoy y Nadiar ubican la temperatura entre los factores que alteran la frecuencia de los modos normales de vibración en un tubo, pues de ella depende la velocidad del sonido (Godoy y Nadiar, 1988: 14). Esto incide en las capacidades del instrumento y el instrumentista, como bien lo señalan los lakitas desde su experiencia.

Los lakitas de Arica poseen una gran movilidad, sus relaciones de parentesco y comercio con personas de pueblos del interior los llevan hacia allá, periódicamente, para tocar en fiestas religiosas o familiares. El clima de Arica es de tipo costero desértico, con una temperatura promedio de $18^{\circ} \mathrm{C}$, casi sin precipitaciones y sin grandes oscilaciones térmicas entre el día y la noche. Alli está la principal diferencia con los climas del interior, de tipos desértico normal y desértico de altura, donde en la noche las temperaturas pueden caer bajo los $0^{\circ} \mathrm{C}$, luego de un día con $30^{\circ} \mathrm{Co} 5^{\circ} \mathrm{C}$ como máximas.

Por ello requieren que sus instrumentos sepan responder de buena manera en condiciones ambientales muy distintas. Alfredo resuelve en favor de las hechas con caña, "siempre roncan" y "suenan más rico". Esos instrumentos desplegarían en todo momento y bajo cualquier circunstancia un buen sonido vivido. Más Alfredo no puede desconocer los riesgos físicos y económicos implicados en aquellas lakitas que "se rompen fácilmente".

Con este dilema en mente, los lakitas analizan los tubos de PVC. La industria los ha diseñado 
con fines diversos, poseen propiedades específicas relacionadas con la presión y temperatura de aquello que deben conducir. Es posible entonces, que se obtengan desempeños distintos según el tipo de tubo que sea utilizado en la lakita. Algunos son más "blandos", es decir, más fáciles de tocar. Pero un buen lakita siempre será capaz de hacerlos roncar.

En ese tiempo, es que también por tradiciones y amistad uno empezó a aprender. Porque tampoco es tan fácil aprender a tocar zampoña. Si no es nada fácil, hay que saber tocar, hay que saber emboquillar. Porque no es llegar y soplar al lote, hay que emboquillar y hay que sonar fuerte. Entonces, el que toca más fuerte, como que es el mejor músico. El que ronca la caña, suena la caña, así [hace sonar su instrumento] roncar la caña, en todas las tradiciones. Entonces, uno va como adquiriendo popularidad entre la misma gente. [Julio Clavijo]

Retomamos aquí la principal virtud que debe alcanzar un intérprete para ser reconocido como uno de buen nivel. Julio lo señala, "el mejor músico" es aquel que hace "roncar la caña, en todas las tradiciones". Hace roncar su instrumento en cualquier evento, especialmente, en aquéllas consideradas como más propias y significativas por los oyentes. Entre ellos -que no necesariamente son músicos- un buen intéprete va "adquiriendo popularidad", cada vez que despliega un buen sonido vivido en ocasiones que les son importantes.

Llegar a convertirse en un lakita reconocido "no es nada fácil". Primero "hay que saber tocar", se ha de aprender a ejecutar el instrumento, pero más específicamente, "hay que saber emboquillar". Esto es, se debe dominar la habilidad de colocar la boca en una relación espacial precisa con cada tubo, para poder introducir adecuadamente el soplido y así obtener un sonido intenso, "fuerte".

Por otra parte, es necesario contar con un buen instrumento para lograrlo. A los fabricantes se les pide que cada lakita "suene parejito, para hacerla roncar" [Osvaldo Tobar].

Cuando uno dice roncar la zampoña, es soplar correctamente el instrumento, pa'que salga la nota que ese tubo tiene de forma correcta. Porque muchas veces la persona, ya sea por no dominar bien el instrumento, vayan a saber porque, como que lo chiflan ¿Me entiende esa expresión? Llegan y soplan no más, al lote no más y sale un sonido medio chiflado. Entonces roncar es emboquillar bien, es poner bien el aire dentro del tubo pa'que suene. Roncar se dice. Pero no es que ronque, si no que vibra apropiadamente, en ese tono. Por eso roncar. A veces son tubos grandes, cuando se sopla ese instrumento vibra. Claro si uno le pone así [con gesto seguro] vibra fuerte, así como ronco. Es que depende del tono poh. Si mientras más bajo, más ronco el tono. Muchos soplan de una manera inapropiada, entonces se sale el aire. O sea sale el sonido, así muy agudo, como medio desafinado. No es el sonido apropiado, porque sale medio desafinado en el fondo. En eso hay que roncar la zampoña. Es mandar, dar, el aire apropiado. De tal forma que salga el sonido bien, correctamente. Muchos tocan así [con el tubo más abajo de la boca] emboquillan mal. Porque no tienen a veces la enseñanza apropiada. Yo recuerdo esa expresión, estaba muy joven 
cuando la escuchaba a los músicos antiguos, entre ellos mi padre. Acá mismo [en esta casa], cuando llegaban jóvenes nuevos, me acuerdo, entonces les llamaba la atención. Decía, "hay que roncar la zampoña, no hay que tocar de esa manera". Entonces les enseñaba como había que tocar, como había que soplar, como había que emboquillar. No era llegar y hacer. Tiene su técnica, así que uno lo domina. Entonces mi padre sabia altiro. A veces habían como doce músicos, de repente uno sacaba un sonido que no tenia nada que ver. No es que estuviera dando otra nota, si no en la misma nota, pero no el sonido. Le decía "tú ya estás", le decía altiro. Tenía un oído, pero pucha. [Adolfo Aica]

Hacer roncar se basa en "soplar correctamente el instrumento", con el objetivo de "que salga la nota que ese tubo tiene de forma correcta". En palabras del sonidista Andrés Fortunato, es "conseguir que suene la nota fundamental, con una interpretación técnicamente correcta, logrando que el sistema entre en resonancia" (Fortunato, 2010).

Los malos instrumentistas "llegan y soplan no más", no manejan la técnica apropiada. Como consecuencia, obtienen un sonido "chiflado", "muy agudo", "medio desafinado". Esto, porque "se sale el aire", no logra llenar o vaciar de manera óptima el tubo. Aciertan en la nota a ejecutar, pero no el sonido anhelado. En pocas palabras, "no es el sonido apropiado".

Al "mandar, dar, el aire apropiado", se despliega "el sonido bien, correctamente". La clave está en dominar las acciones de emboquillar, cuidar la disposición espacial de los tubos del instrumento en relación con la boca y el resto del cuerpo del instrumentista; y de soplar, controlar la intensidad y velocidad con que se hace ingresar el aire exhalado en cada tubo. Para así "poner bien el aire dentro del tubo pa'que suene", lo cual se puede aprender de un buen maestro. Si se logra que cada tubo "vibre fuerte", entonces podemos decir que se hace roncar la lakita.

\section{La caña prestigiosa}

Si bien existe la sensación, medianamente generalizada, de que ha desaparecido. "Ya no hay grupos con caña, ya no hay ya" [Adolfo Aika]. "La caña ya se perdió ya" [Martín Coya]. O tal vez por ello, se ha vuelto un material que prestigia a quien lo ostente.

Los niños (como Abdón Cayo y Eduardo Choque en su tiempo) ya no fabrican sus primeras lakitas jugueteando, en poblados del interior, con algunas cañas recogidas casualmente, acompañados de sus amigos. Sino que lo hacen en sus colegios, con tubos de PVC, como parte de su trabajo en clases. Las agrupaciones musicales que quisieran tener lakitas de caña, las ven como lejanas en el tiempo (están en el pasado) y en el espacio (están en Bolivia). 
Dos comparsas ariqueñas, Phusiri Marka y Prisioneros del Folclor, de larga y reconocida trayectoria, nacidas una vez que el vinilo ya había alcanzado hegemonía en la fabricación de lakitas, están usando instrumentos hechos con caña. Dado su elevado costo, han debido gestionar el financimiento desde fondos públicos concursables y realizar esfuerzos económicos personales para conseguirlo.

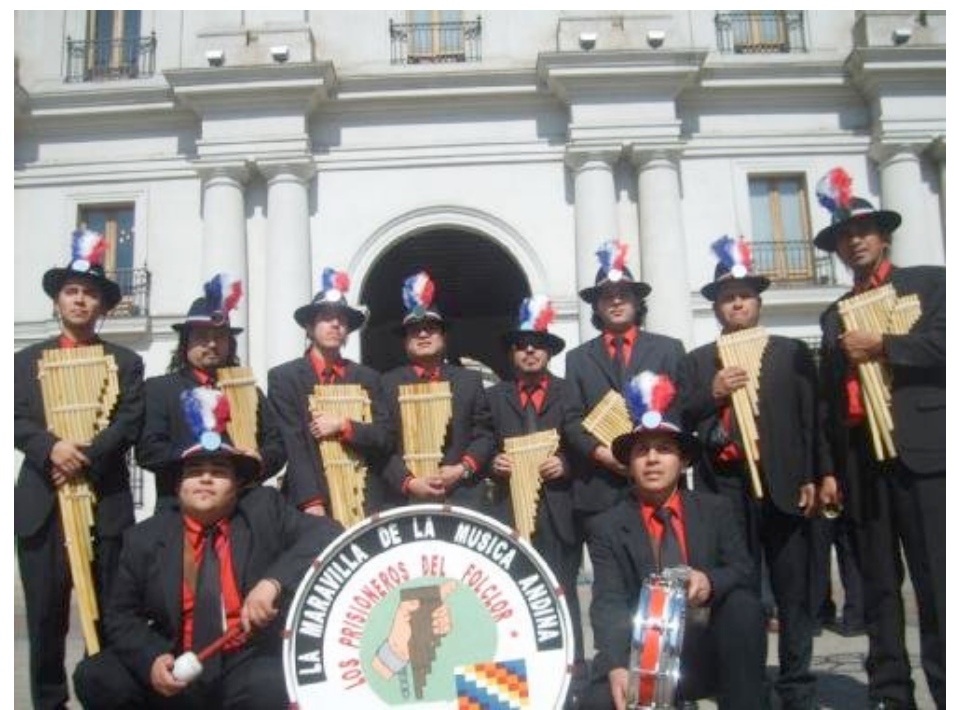

Prisioneros del Folclor viaja a Santiago, capital del país, para interpretar con sus lakitas de caña el himno nacional, en el marco de la muestra "Arica. Cultura Milenaria", realizada en el Centro Cultural Palacio de La Moneda, el año 2008.

Posan frente a la Casa de Gobierno. Fotografía gentileza de Schmeling Salas. 


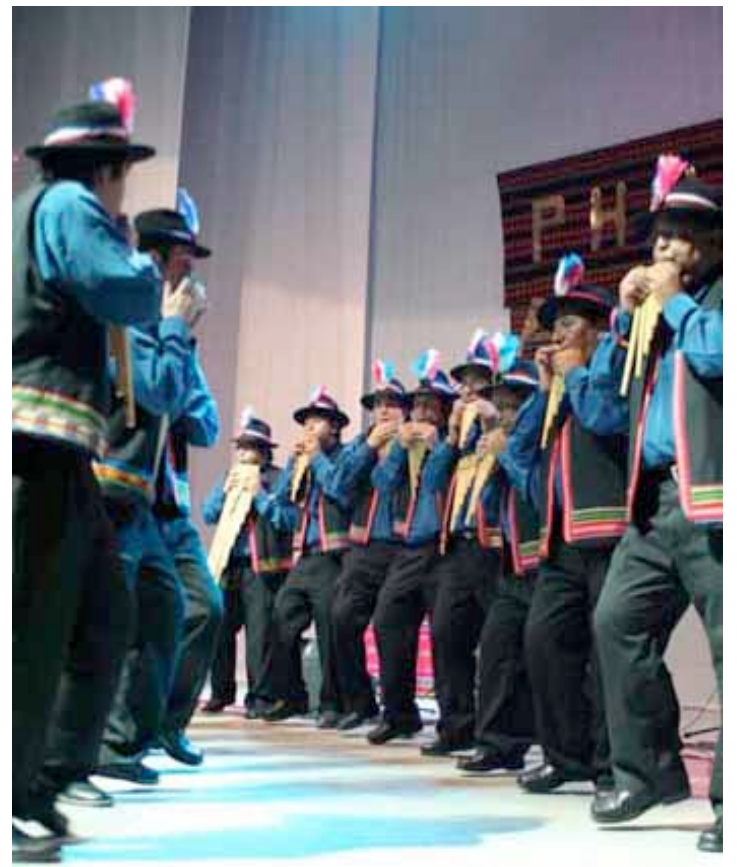

Phusiri Marka presenta su segundo disco en el Teatro Municipal de Arica.

Fotografía de Gerardo Mora, enero de 2009.

Si se dejan fuera consideraciones sobre su repertorio musical, la sola presencia de instrumentos fabricados con caña, establece un preciado vínculo entre estos músicos y los sonidos ancestrales (sonidos vividos) presentes en su propia memoria y la de sus escuchas. Se trata de agrupaciones que buscan, de maneras muy distintas, un sonido más tradicional o autóctono. Bajo nociones que incluyen criterios estéticos y atienden a la situación sonora creada por la caña.

No obstante, ambas comparsas conservan sus lakitas de PVC para ir a los pueblos del interior. La caña suele ser reservada para la exhibición folklórica, la experimentación musical o la recuperación de antiguas canciones.

Los lugares originarios de varias melodías interpretadas hoy por los lakitas en Arica, aquéllos en que nacieron los sopladores más antiguos y respetados, escuchan hoy el sonido del vinilo. La caña circula por espacios y tiempos disímiles, donde su fragilidad y delicadeza encuentran cuidado y abrigo, sus desventajas físicas comparativas dejan de ser relevantes, y las económicas encuentran compensación. Se trata de teatros, centros culturales y otros establecimientos de carácter urbano.

De acuerdo a la etnógrafa británica Sara Cohen, "la producción del lugar a través de la música es siempre un proceso político y la música ha demostrado estar implicada en las politicas del lugar, la lucha por la identidad y la posesión de poder y prestigio" (Cohen, 1995: 445). La materialidad de las lakitas es un asunto político y, a materiales distintos corresponden lugares diversos. O más bien, se 
construyen lugares diferentes. El vinilo es innovación y popularidad, la caña es tradición y prestigio. Ambos son continuidad y hacen roncar sus lugares.

\section{Cacharpaya $^{36}$}

El presente artículo se despliega en tres áreas temáticas: (i) cómo sucedió el paso de la caña al plástico como material preferente para la fabricación de lakitas en Arica, (ii) de qué manera son entendidas, hoy, las diferencias entre las lakitas de ambos materiales y, (iii) qué es hacer roncar una lakita. Lo anterior, con las comparsas de lakitas de la ciudad de Arica como coto y referente.

La hipótesis que anima estas páginas propone que el paso de caña a vinilo, es un cambio tecnológico que se sostiene en una manera particular de pensar este instrumento y su musicalidad, la cual posee una larga data $y$, que dicho cambio ha sido agenciado por sus propios fabricantes e intérpretes.

Hipótesis que se sostiene en los siguientes antecedentes: (1) La presencia milenaria de las lakitas en Los Andes, información sustentada en numerosos estudios arqueológicos. (2) La existencia de lakitas prehispánicas, en la zona andina, fabricadas con cerámica, hueso, metal o caña. (3) Las numerosas modificaciones de carácter sonoro, estético, social, práctico entre otras, que han experimentado desde su aparición en la zona de Arica, hace más de quinientos años atrás.

Con esto en mente, revisemos los principales temas abordados:

(i) La llegada (invención) de las lakitas de plástico en Arica, a fines de los años sesenta, se sostiene en las redes de relaciones sociales de Martín Coya. Las cuales dan cuenta de la existencia de un sistema de relaciones, desplegado tanto en el nivel de individuos y hogares como en el colectivo, entre las localidades andinas y las áreas de migración. Esto, según el modelo de la "regionalización de la sociedad aymara" ${ }^{\prime 37}$, propuesto por el antropólogo Hans Gundermann (2001a y otros), bajo un enfoque que considera la dicotomía continuidad/cambio en la sociedad andina.

Más queda un hilo por seguir en esa historia ¿Cómo se da la invención de las lakitas de plástico por parte de Pascual Hidalgo? Además, es necesaria una profundización en el estudio de las redes de relaciones entre los lakitas en Arica, y de sus vínculos con Iquique y los poblados del interior. Junto con un análisis de la incidencia de fenómenos con mayor cobertura: gobiernos nacionales, avatares

\footnotetext{
${ }^{36}$ Corresponde a la despedida, momento en que cada agrupación musical interpreta un tema alusivo al final de la fiesta y/o un conjunto de canciones que resumen su participación en ella.

${ }^{37}$ Cursivas en el original.
} 
económicos globales, migraciones transnacionales, entre otros.

(ii) En el momento del cambio, las diferencias entre las lakitas de ambos materiales, favorecieron a aquéllas de plástico. Decisión tomada en base a criterios prácticos, fundados por sus características económicas y físicas, en las cuales coincidimos con Díaz y Mondaca (1998). Accesibilidad y fragilidad son las claves. Las cañas de buena calidad deben ser traídas desde los yungas fluviales de la actual Bolivia, lo cual hoy es muy costoso para los lakitas. Por su parte, los tubos plásticos se pueden adquirir a bajo precio en ferreterías y/o recoletar en construcciones antiguas o deshabitadas. En términos físicos, el Policloruro de Vinilo, aunque es igualmente liviano, posee una mayor resistencia mecánica y al impacto que la caña. Como consecuencia, las lakitas de plástico requieren de menores cuidados por parte del intérprete.

Si bien no hay acuerdo entre los músicos respecto de qué material brinda una mejor experiencia sonora. Es claro que, sea con caña de un valle desértico, caña de los yungas o plástico industrial, si se cuenta con un buen instrumento y un buen instrumentista, se obtiene un buen sonido vivido. Es decir, se hace roncar la lakita.

Por su parte, la caña pasa a ser un insumo de la memoria, con el cual se construyen por evocación los lugares de origen de las poblaciones que migraron a Arica desde el interior. Y, entre algunos músicos se usa para el folklore y la experimentación. Hoy en día, el vinilo es el preferido para ir a tocar a las fiestas de los pueblos.

Queda abierto el oído a las diferencias, entre caña y plástico, propias de la fabricación de las lakitas. Y a cómo, en estructuras y sonidos musicales, las experiencias de migración y viaje puedan estar expresadas a través de códigos semióticos culturales específicos.

(iii) Hacer roncar es lograr la correcta ejecución de una lakita. Aquí estamos frente a una continuidad en el sonido vivido. Ya en el relato de Martín Coya se devela que, entre las lakitas de caña y plástico, "tiene otro sonido ese instrumento". No obstante, quien domine las acciones de emboquillar y soplar, si dispone de una lakita bien fabricada, mantenida y ajustada, podrá hacerla roncar fácilmente.

\section{$\operatorname{Diana}^{38}$}

En las lakitas de Arica estamos ante un campo donde circulan -en palabras del etnohistoriador

\footnotetext{
${ }^{38}$ Pieza musical, breve e intensa, con la que cada comparsa cierra, momentánea o definitivamente, su participación.
} 
José Luis Martínez- “saberes andinos prehispánicos”. En ellas se aprecia una manera de pensar, utilizar e interpretar la música, propia de Los Andes. Argumento que se sostiene al observar la continuidad de (a) su ingeniería y arquitectura; (b) su técnica de ejecución; (c) las redes sociales que posibilitan su cambio y permanencia a la vez que, de cierta manera, tienen sustento en estos aerófonos y; (d) la experiencia sonora que brindan. Antecedentes expuestos sin desatender a las diferentes profundidades cronológicas con que han sido demostrados.

En este estudio hemos abordado cómo el cambio tecnológico de un instrumento musical, de data milenaria en Los Andes y carácter masivo en la Arica contemporánea, se da en condiciones de continuidad sonora y cultural. Las llamadas músicas tradicionales poseen "una historia constantemente reinterpretada y adaptada a las exigencias de cada época, exigencias que están en relación coyuntural con los cambios ideológicos, demográficos, mediáticos, económicos, etc.” (Pelinski, 1997: [3]). La caña es un material que en ningún caso está obsoleto sino que ha sido reposicionado. El paso al plástico no es una respuesta forzada ante la modernidad, ni una maniobra de supervivencia. Es una modificación agenciada por los propios lakitas, en el marco de una búsqueda musical incesante, donde el buen instrumentista persigue hacer roncar un buen instrumento, en todo momento y lugar. Corresponde admirar a quienes pusieron vinilo allí donde antes hubo materiales recolectados en áreas agrestes. Porque no existe un único proceso correcto o "natural” de acción o producción musical, ni, ciertamente, un único patrón "tradicional” (Finnegan, 2002: [16]). En este caso, ingenio y habilidad componen parte de la tradición musical. Allí radica su belleza humana.

\section{Dedicatoria y agradecimientos}

Dedico el presente artículo a la memoria de don Juan Solar González, en profundo agradecimiento por su invaluable e incondicional apoyo al sueño de [AZAPA]. Quiero reconocer el lugar central que ocupan en estas páginas mis compañeros de viaje y reflexión: Andrés Fortunato, César Borie y Juan Solar. Gracias por creer, hace ya seis años, que existía una fiesta para los muertos. También agradezco a Pedro Honorato y Carmen Devia, nuestros padrinos en el valle de Azapa. Saludo con cariño a su nieto recién nacido, Vicente. Mi gratitud a todos los músicos que conversan y comparten con nosotros en cada rincón donde nos encontramos, su aporte a este trabajo es incomensurable. A nuestros amigos en Arica y San Miguel. Al Ño Carnavalón, por cumplir con fe. A José Luis Martínez, por su confianza, y a Paula Martínez, por su amistad. A María Carolina Odone, por 
su mirada y compañía en esta escritura.

\section{Referencias}

ACEVEDO, María Isabel; GÁLVEZ, Rodolfo y RAAB, Marina Los migrantes de los pueblos del interior del Departamento de Arica y su asimilación al contexto de la ciudad de Arica, Tesis licenciatura en Sociología, Universidad de Chile, Santiago, 1970 (?)

ARANCIBIA, Camila y SILVA, Francisco "Música bajo la tierra" en MORA [ed.] Lakitas en Arica, Santiago de Chile, Azapa Producciones Ltda., 2010.

AUGOYARD, Jean-François “L’entretien sur écoute réactivée”" en GROSJEAN y THIBAUD [eds.], L'espace urbain en méthodes, Éditions Parenthèses, pp. 127-152, 2001

BATESON, Gregory Pasos hacia una ecología de la mente, Ediciones Planeta-Carlos Lohlé, Buenos Aires, 1991

BENAVIDES, Renato Espacio de accion del migrante aymara en Arica. Estudios de casos, Seminario para optar al título de profesor de Historia y Geografía. Universidad Tarapacá de Arica, Arica, 1993 BORIE, César y MORA, Gerardo "Historia reciente de las lakitas en Arica" en MORA [ed.] Lakitas en Arica, Santiago de Chile, Azapa Producciones Ltda., 2010

BRUNO, Fabiana y SAMAIN, Etienne "Una Cartografía Verbo-Visual de la Vejez: Fotobiografías y montajes de memorias" en Revista Chilena de Antropología Visual, número 10, pp.30-53, Santiago de Chile, diciembre, 2007

BUNSTER, Ximena "Talking pictures: a study of proletarian mothers in Lima, Peru" en Studies in the Anthropology of Visual Communication, número 5(1), pp.37-55, 1978

CABEZAS, Andrea "Retratos, recuerdos y novedades de la colonia holandesa: Gorbea, primera mitad del Siglo XX" en QUIROZ [ed.] Etnografias Mínimas, pp.187-192, Editorial Andros, Santiago de Chile, 2007

CALDEROLA, Victor "Visual contexts: a photographic research method in anthropology" en Studies in Visual Communication, número 11(3), pp.33-55, 1985

CANDAU, Joël Memoria e Identidad, Buenos Aires, Ediciones Sol, 1998

COBO, Bernabé Historia del NuevoMundo, volumen II, Biblioteca de Autores Españoles, tomo XCII, Madrid, 1956 [1653]

COHEN, Sara "Sounding out the city: music and the sensous production of place"en Transactions of the Institute of Britih Geographers, NS 20, pp. 434-446, Royal Geography Society, 1995

COLLIER, John "Photography in Anthropology: A Report on Two Experiments" en American

Ethnologist, volumen 59, número 5, páginas 843-859, Universidad de California, 1957

DAUELSBERG, Percy "Prehistoria de Arica" en Diálogo Andino, número 11/12, Arica, 1992-1993

DÍAZ, Alberto y MONDACA, Carlos “Toquen, soplen sin parar. Antecedentes etnomusicológicos de las lacas tarapaqueñas” en Percepción, número 2, pp.73-94, Arica, 1998

FELD, Steve "From Ethnomusicology to Echo-Muse-Ecology" en The Soundscape Newsletter, número 08, junio, 1994

FINNEGAN, Ruth “¿Por qué estudiar la música? Reflexiones de una antropóloga desde el campo” en Revista Transcultural de Música - Transcultural Music Review, \#6, 2002

FOCACCI, Guillermo "Relatos de cronistas sobre instrumentos musicales andinos. Presencia de ellos en la arqueología de Arica" en Diálogo Andino, No19, pp. 33-50, Universidad Tarapacá de Arica, Arica, 2000

FORTUNATO, Andrés “La zampoña ariqueña” en MORA [ed.] Lakitas en Arica, Santiago de Chile, Azapa Producciones Ltda., 2010. 
GODOY, Osvaldo y NADIAR, Nicolás Acústica de la zampoña. Tesis de titulacion en Tecnología en Sonido, Universidad de Chile, Santiago de Chile, 1988.

GONZÁLEZ, Héctor Características de la migración Campo-Ciudad entre los Aymaras del Norte de Chile, Corporación Norte Grande, Serie Documentos de Trabajo, Arica, 1996a

GONZÁLEZ, Héctor Los migrantes Aymaras en La Ciudad: Acceso a Educación, Vivienda y Salud, Corporación Norte Grande, Serie Documentos de Trabajo, Arica, 1996b GONZÁLEZ, Héctor "La inserción económica de los migrantes Aymara en la Ciudad: El Trabajo como empresa familiar y la Reproducción Cultural" en Actas Segundo Congreso Chileno de Antropología, Tomo I, pp. 315-324, Santiago de Chile, 1997a

GONZÁLEZ, Héctor Características de la Inserción de Aymaras chilenos y bolivianos en el área de Arica, Taller De Estudios Andinos, Serie Documentos de Trabajo, Arica, 1999a GONZÁLEZ, Héctor La Posición de Aymaras chilenos y bolivianos en la estructura de tenencia de la tierra de los valles de Lluta y Azapa, Taller De Estudios Andinos, Serie Documentos de Trabajo, Arica, $1999 \mathrm{~b}$

GONZÁLEZ, Héctor; TABILO, Kapris y VENEGAS, Franco Las Agrupaciones de Residentes Aymara Urbanos en el Norte de Chile: Adaptación a la Ciudad y vínculos con las Comunidades de Origen, Corporación Norte Grande, Serie Documentos de Trabajo, Arica, 1996

GONZÁLEZ, Sergio Hombres y mujeres de la pampa. Tarapacá en el ciclo de expansión del salitre (1880-1930), DIBAM-UNAP-LOM, Santiago de Chile, 2002

GREBE, María Ester Aspectos básicos de la cosmovisión aymara y mapuche, BAFONA, MINEDUC, Santiago de Chile, 1985

GREBE, María Ester "Migración, identidad y cultura aymara: puntos de vista del actor" en Revista Chungará, N¹6, Universidad Tarapacá de Arica, Arica, 1986

GREBE, María Ester Culturas indigenas de Chile: un estudio preliminar, Pehuén, Santiago de Chile, 1998

GUNDERMANN, Hans “Procesos regionales y poblaciones indígenas en el norte de Chile. Un esquema de análisis con base en la continuidad y los cambios de la comunidad andina" en Estudios Atacameños, №21, pp.89-112, 2001a

GUNDERMANN, Hans Comunidad, sociedad andina y procesos socio-históricos en el norte de Chile, Tesis Doctoral, Centro de Estudios Sociológicos, El Colegio de México, 2001b GUNDERMANN, Hans Sociedad aymara y procesos de modernización durante la segunda mitad del siglo XX, Comisión Verdad Histórica y Nuevo Trato, Santiago de Chile, 2002

HARPER, Douglas “Talking about pictures: a case for photo elicitation” en Visual Studies, volumen 17, número 1, pp.13-26, 2002

HUDSON, Ray "Regions and place: music, identity and place" en Progress in Human Geography, 30, 5, pp. 626-634, 2006

JORDÁN, Laura "Música y clandestinidad en dictadura: la represión, la circulación de músicas de resistencia y el casete clandestino" en Revista Musical Chilena, año LXIII, julio-diciembre, $\mathrm{N}^{\circ} 212$, pp. 77-102, 2009

LECAROS, Miguel Migraciones de poblaciones andinas al valle de Azapa, Seminario para optar al título de Profesor de Historia y Geografía, Universidad Tarapacá de Arica, Arica, 1985 MARTÍNEZ, José Luis “Imágenes y soportes andinos coloniales. Notas preliminares" en Revista Chilena de Antropología Visual, número 5, pp. 113-132, Santiago de Chile, julio, 2005

MARTÍNEZ, Soledad "La ciudad percibida: cuestiones metodológicas en la investigación de ambientes sonoros urbanos" en Revista Iluminuras, Vol. 11, N 25, 2010

MERCADO, Claudio "Música y estado de conciencia en fiestas rituales de Chile Central. Inmenso puente al universo" en Revista Chilena de Antropología, número 13, páginas 163-196, Universidad de 
Chile, Santiago, 1995-1996

MONTAGUE, Jane "Family photographs as a topic for conversation" en ROBINSON, KELLY y MILNES [eds.] Narrative \& Memory, Universidad de Huddersfield, Reino Unido, 2007

MORA, Gerardo Eric Boman. Aislamiento, etnografia y fotografia en la antropologia del Norte

Grande de Chile, Tesis para optar al título profesional de Antropólogo Social, Universidad de Chile,

Santiago, 2009

MOSTNY, Grete "Excavaciones en Arica" en Boletín del Museo de Historia Natural, tomo No XXII, Santiago de Chile, 1944

PÉREZ DE ARCE, José Música en la Piedra. Música Prehispánica y sus Ecos en Chile Actual, Museo Chileno de Arte Precolombino, Santiago de Chile, 1995

PÉREZ DE ARCE, José “El sonido rajado: una historia milenaria” en Valles. Revista de Estudios

Regionales, año 3, número 3, Museo de La Ligua, 1997

PÉREZ DE ARCE, José "Sonido Rajado: the sacred sound of pifilca flutes" en The Galpin Society

Journal, Volumen 51, páginas 17-50, Galpin Society Stable, 1998

PÉREZ DE ARCE, José "Sonido Rajado II" en The Galpin Society Journal, volumen 53, abril, páginas 233-253, Galpin Society Stable, 2000

PELINSKI, Ramón 'Dicotomías y sus descontentos: Algunas condiciones para el estudio del folclor musical" en Txistulari, N 172, octubre, 1997

PINK, Sara Women and Bullfighting: gender, sex and the consumption of tradition, Berg, Oxford, 1997

RADLEY, Alan y TAYLOR, Diane "Images of recovery: a photo-elicitation study on the hospital ward” en Qualitative Health Research, número 13, pp.17-99, 2003

SILVA, Francisco Sonido de Arica en la órbita Tiwanaku, Informe de Práctica profesional,

Departamento de Antropología, Universidad de Chile, 2004 (Ms)

STOKES, Martin Ethnicity, Identity and Music: The Musical Construction of Place, Berg, Oxford, 1994

TUDELA, Patricio El Estado y la Sociedad Chilena ante los Aymaras de Tarapacá (1era Región de Chile): Factores y Consecuencias de su Integración entre 1930-1973, Comisión de Verdad Histórica y Nuevo Trato, Grupo de Trabajo Pueblos Indígenas del Norte, 2002

VALENCIA, Américo “Jjaktasiña Irampi Arcampi. El Diálogo Musical: Técnica del Siku Bipolar” en Boletín de Lima, número 22, pp. 8-21, julio, 1982

VAN KESSEL Juan Holocausto al Progreso, HISBOL, 1992a

VAN KESSEL Juan Aica y la Peña Sagrada. Ediciones El Jote Errante, Iquique, Chile y CIDISA, Puno, Perú, 1992b

WINNER, Langdon Autonomous Technology: Technics-out-of-Control as a Theme in Political Thought, MIT Press, 1977

WINNER, Langdon "Do Artifacts Have Politics?" en MACKENZIE et al. [eds.] The Social Shaping of Technology, Philadelphia, Open University Press, 1985

WRIGHT, Pablo Cuerpos y espacios plurales: sobre la razón espacial de la práctica etnográfica, Serie Antropología, número 242, Universidad de Brasilia, 1998 